\title{
AN ECONOMIC STUDY ON THE ROLE OF WATER USERS ASSOCIATIONS IN AGRICULTURAL DEVELOPMENT OF MAIZE CROP IN BEHAIRA GOVERNORATE
}

\author{
ASMAA SALEH ABD EL-MONEM
}

Agricultural Economics Research Institute, ARC, Giza

(Manuscript received 29 December 2015)

\begin{abstract}
$\mathrm{T}$

he establishment of water users associations (WUAs) is one of the main objectives of the Irrigation Improvement Project (IIP). These WUAs are under the supervision of the Ministry of Water Resources and Irrigation. The current research aims at measuring the impact of WUAs in agricultural development in Behaira Governorate focusing on their role in the production of summer maize as one of the main crops in the Governorate. The results revealed that.
\end{abstract}

1 - The average cost of one irrigation for maize reached about LE 22.11 per feddan after joining the WUA, representing about $49.5 \%$ of the costs before joining the WUA estimated at about LE 43.8 per feddan.

2 - Joining the WUA can increase maize production in the Governorate to about 258.1 thousand ardab in the governmate these and decrease the irrigation cost of maize to about LE 153.1 per feddan., decreasing the costs of production for maize grown in Behaira Governorate to about LE 28.4 million, release an area used to be cultivated by maize of about 16.2 thousand feddans, contributing to saving irrigation water of about 43.2 million cubic meters in the Governorate and increase the net revenue and the net return per one pound for maize production by joining the WVA.

3 - The average total costs of fuel, depreciation and maintenance of electric irrigation machines were lower than those for disiel irrigation machines by about LE 4.5 per hour.

4 - The average cost of lifting one cubic meter by electric irrigation machine reached about LE. 0.016 , as compared to about LE. 0.010 for disiel irrigation machines.

5 - The average energy for lifting one cubic meter by electric irrigation machine reached about 0.024 mega calory, as compared to about 0.086 mega calory for disiel irrigation machines. The results obtained for the economic and technical efficiency indicators, prove that the electric irrigation machines was more efficient than those runned by disiel.

The study recommends paying more attention to improve the knowledge of farmers regarding water problems, the importance of water rationalization to sustain water resources, and ecouraging farmers to join WVAs 


\section{دراسة إقتصادية لاور روابط مستخدى المياه \\ فى التنمية الزراعية لمحصول الأرة الثامية

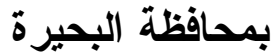

د/ أسماء صالح عبد المنعم

\section{معهز بحوث الإقتصاد الزراعى - مركز البحوث الزراعية \\ مقدمة}

تعثبر الموارد المائية من أهم المحددات الرئيسئة للتتمية الزراعية فى في

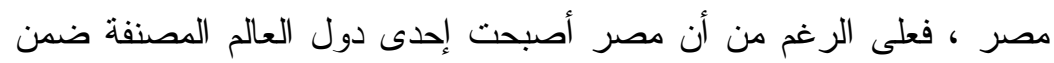

دول الفقر المائي و يبلغ نصيب الفرد فيها من المياه أقل من الف متر مكعب إنب

سنوياً ، وتعتبر مصر من أكثر دول العالم إسر افاً في استخدام المياه ، ويرجع فئاه

ذللك إلى انخفاض كفاءة إستخدام المياه في الزراعة المصرية بسبب ارتفاع

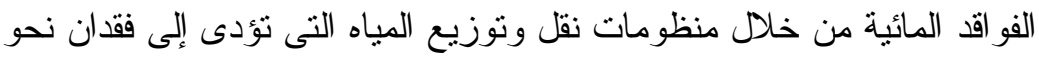

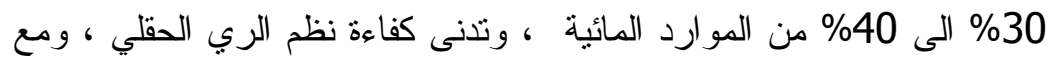
التسليم بصعوبة تفادى فقد المياه بتأثير عمليات النتح و البخر و التسرب النئ المائي

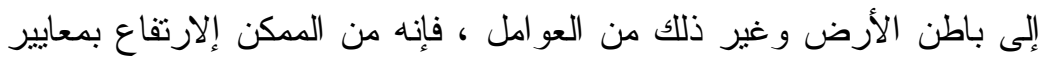

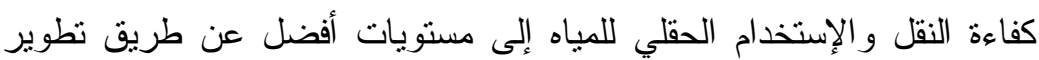

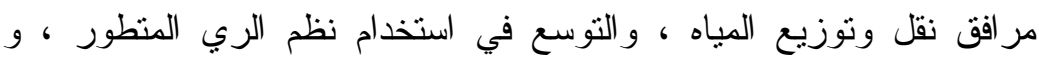

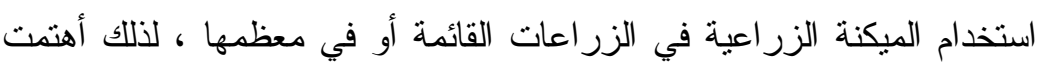
سياسات وز ارة المو ارد المائية و الرى بتطوير الرى عن طريقة الغمر و المتبعة في ضوء الرؤية الاستراتيجية للتتمية الزراعية المستدامة حتى عام 2030

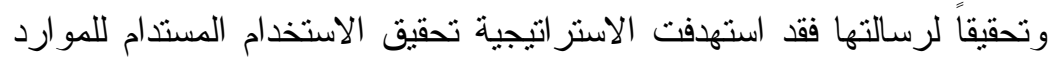

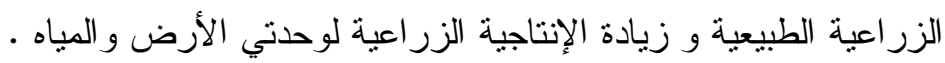

\section{مشكلة البحث}

إستهدفت استر اتيجية التتمية الزر اعية حتى عام 2030 الإرتقاء بكل من كفاءة نقل وتوزيع المياة بدء

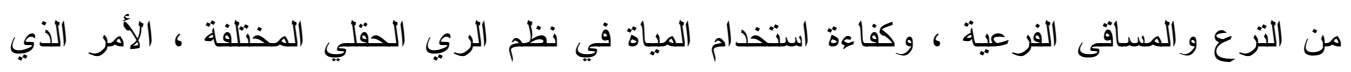

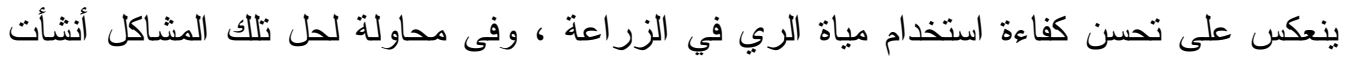

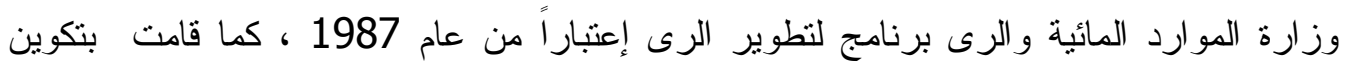

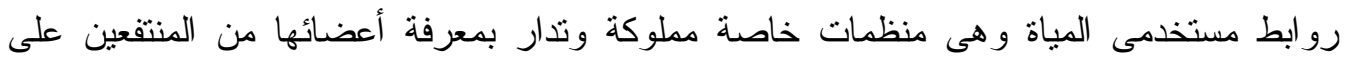
المجرى المائى من إجل فائدتهم ، وتعمل فى مجال نوزيع المياة وأستخدامها ، وجميع الإنشطة

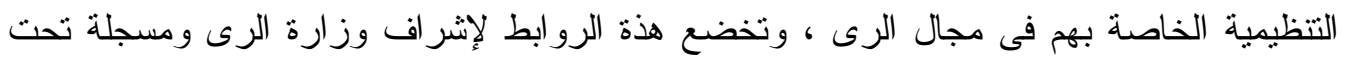


قانون الرى و الصرف رقم 12لسنة 1994 المعدل بالقانون 213 لسنة 1994(1) ـ ومع إنتشار روابط مستخدمى المياة فى التتمية الزراعية بمحافطة البحيرة فإن الأمر يستلزم إجراء دراء داسة إقتصادية للوقوف على دور روابط مستخدمى المياة بمحافظة البحيرة .

\section{هدف البحث}

يستهدف البحث قياس الأثار الإقتصادية لدور روابط مستحدمى مياه الرى فى التتمية الزر اعية

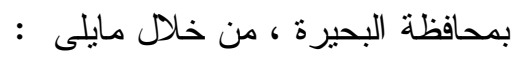

1- التعرف على التوزيع الجغرافي لروابط مستخدمي مياه الري في محافظة البحيرة بالنسبة

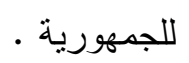

2- قياس الآثار الإقتصادية الناجمة عن الإنضمام لروابط مستخدمى مياه الرى بزمام محافظة

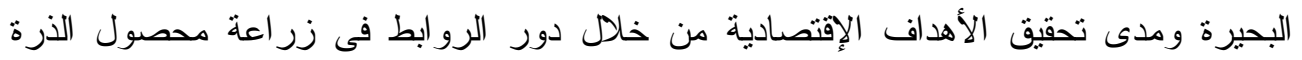
الثامية الصيفى كأحد المحاصيل الرئيسية لعينة الدر اسة بالمحافظة . 3-. در اسة أثز رو ابط مستخدمي مياه الري على تكلفة الرية الو احدة لمحصول الذرة الثامية الصيفى بالمحافظة 4- در اسة عائد الجنية وصافى العائد علي وحدة الطاقة لمحصول الذرة الثامية لمستخدامى روابـط

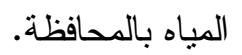
5- در اسة المؤشرات الإقتصادية والفنية لطاقة تشغيل آلة الري لمحصول الذرة الثشامية الصيفى

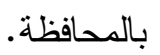
6- تحديد الأهمية النسبية لكلاً من مميز ات ومعوقات الانضمام الى رو ابط مستخدمي مياه الري . الطريقة البحثية ومصادر البيانات

تم إستخدام أساليب التحليل الوصفي و الكمي ، واختبار" ت " لقياس التغير الحادث بعد الانضمام لبات

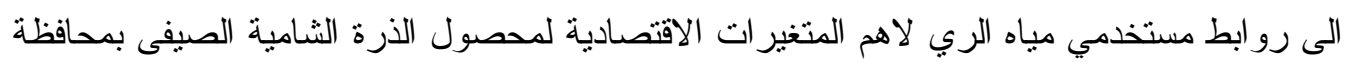

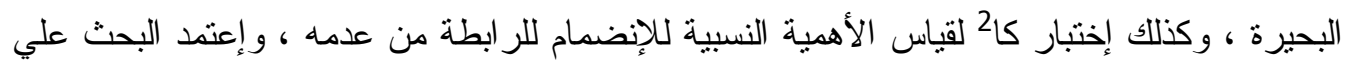

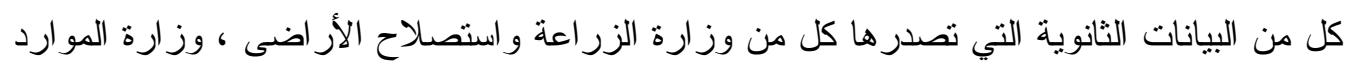

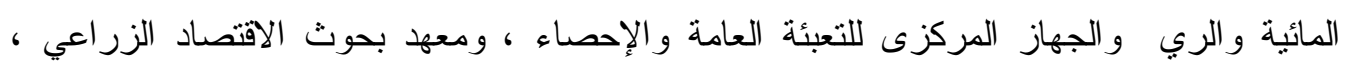

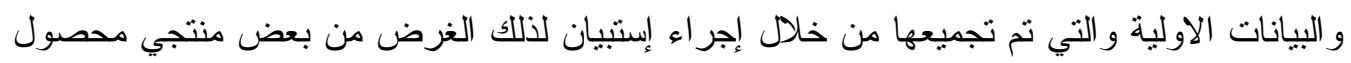
الذرة الثامية الصيفى(2) بمحافظة البحيرة للموسم الزر اعي 2013. عينة الار اسة الزة

إستخدم البحث عينة عمدية متعددة المراحل ففى المرحلة الأولى نم اختبار محافظة البحيرة

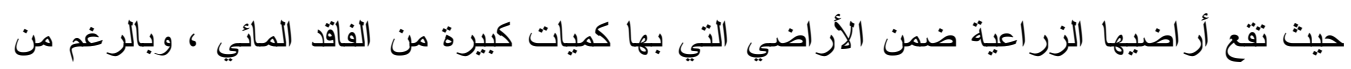

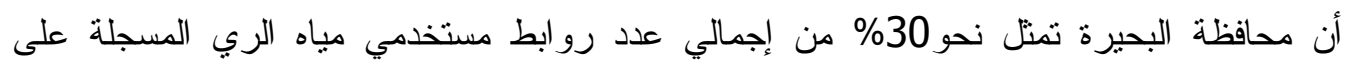


مستوى الجمهورية فإنها لم تلقى حظاً و افر اً من الدر اسة في الدراسات السابقة عن رو ابط مستخدمي المياه ، يوضح الجدول رقم (1) بالملاحق أن محافظة البحيرة تمثل المرنبة الثانية بعد محافظة كفر

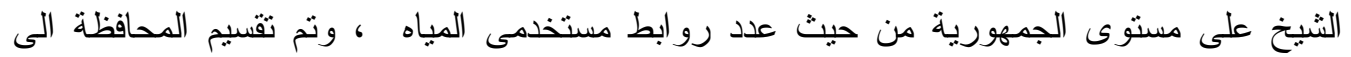
طبقات كل مركز يمنل طبقة ، وتم اختيار مركز كفر الدوار، لأنه يضم عدد كبير من المزارعين

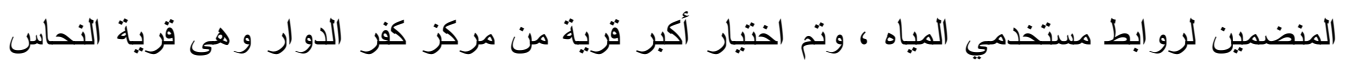

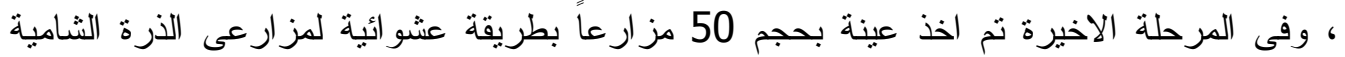
الصيفى كأحد المحاصيل الرئيسة لهذة العينة من حيث استخدامهم للمياه قبل وبعد الإنضمام إلى لى لئه

\section{أهمية البحث}

• تحسين مستوى نظام نوصيل المياه في التزع الرئيسية و الفرعية عبر نركيب منشآت تحكم

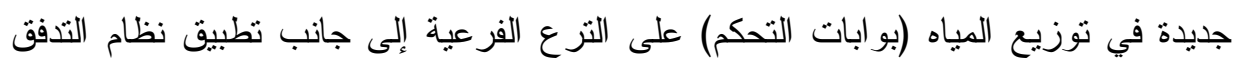
المستمر بدلا من جداول المطارفة وحماية القنوات ونظام قياس المياه عن بعد للسماح بالتحكم المركزي عن بعد في القناطر المقامة على التزع الرئيسية. • تحديث البنية التحتية للري على الترع الفرعية أو مستوى المساقي من خلال تركيب محطة لركة

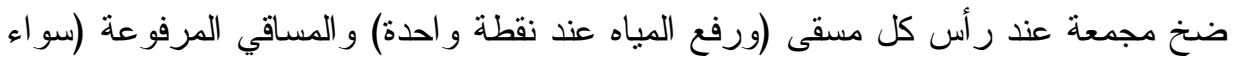

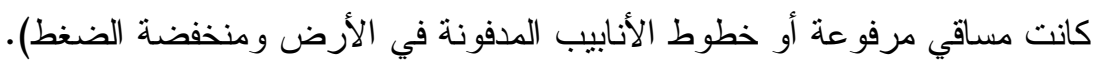

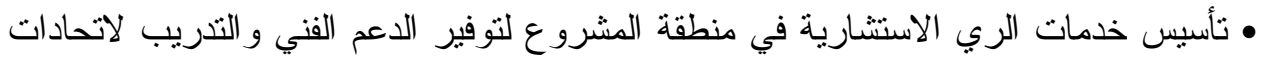
مستخدمي المياه على مستوى المساقي و التزع الفرعية لنتخيل وصيانة المساقي المطورة. • صباغة برنامج بيئي لتقييم الآثار البيئية للمشروع.

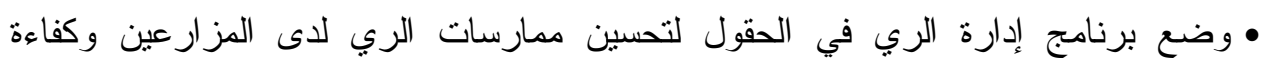
استخدام المياه. • نوفير الدعم المؤسسي لمشروع نطوير الري لتتفيذ المشروع من بينها ندريب العاملين بالمشروع و إمدادهم بالخدمات الاستشارية و الإمكانيات و المعدات.

الإطار النظرى

أولاً :الموارد المائية و إستحداماتها فى جمهورية مصر العربية :

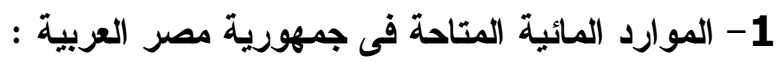

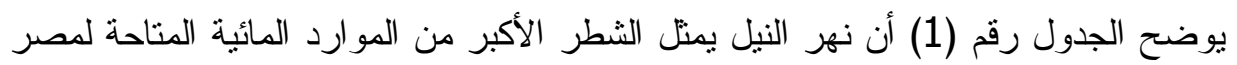
حالياً، إذ يُمنل نحو 73\% من إجمالي المتاح ، حيث تبلغ حصة مصر من مياه النيل 55.50 مليار

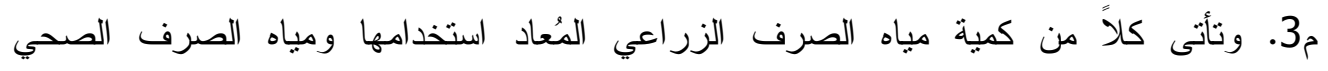
و الصناعي المُعالجة فى المرتبة الثانية وبلغت الأهمية النسبية حوالى 12.4 مليار م3 تُمتل نحو 16\% من جملة الموارد المائية المتاحة ـ و تأتي المياه الجوفية في المرتبة الثالثة بحو الى 6.7 مليهار م3 تُمتل نحو 9\% من جملة الموارد المائية المتاحة ، ويُقدر المتّاح من مياه الأمطار و السيول

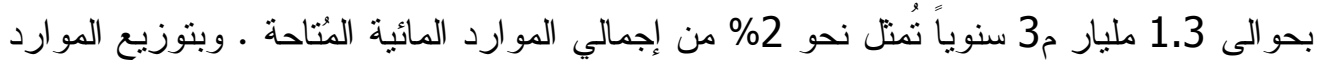


المائية المتاحة على الاستخدامات المختلفة تبين أن القطاع الزر اعي بيتهلك حو الى 62.25 مليار

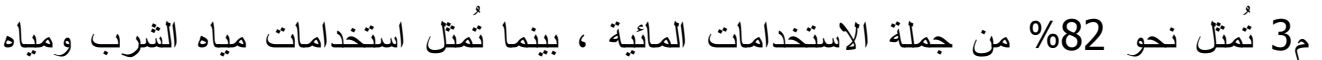

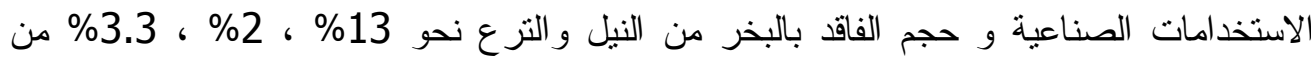
جملة الاستخدامات المائية على الترتيب .

2- التصور المستقبلي للموارد المائية واستخداماتها بجمهورية مصر العربية في عام 2050:

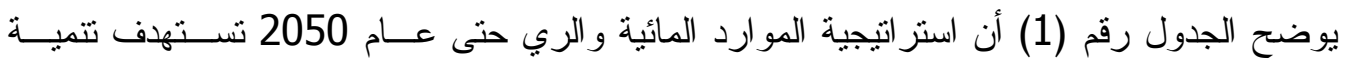

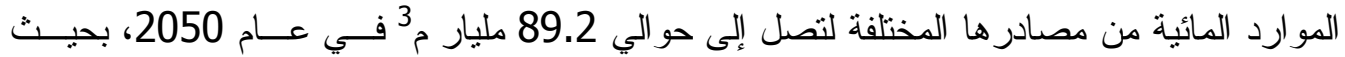

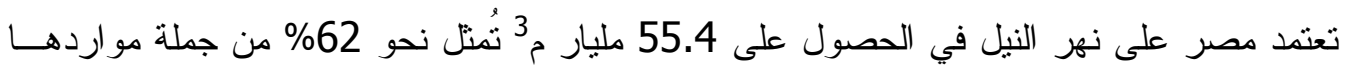
المائية ، في حين تعتمد على كل من المياه الجوفية ، ومياه الصرف الزر اعي و الصناعي و الصــي لهي المعالجة، وعلى مياه الامطار ، وتحلية مياه البحر في الحصول علـى حــ الى لى 12.0، 18.5، 1.5

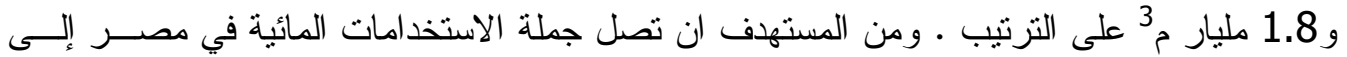

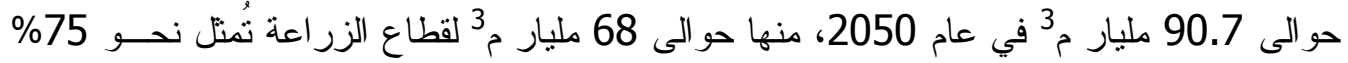

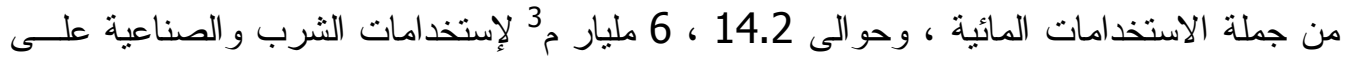

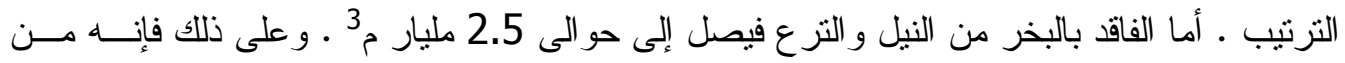

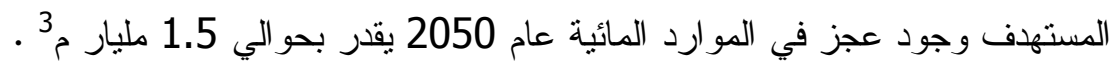
جدول(1) : الموارد المائية واستخداماتها بجمهورية مصر العربية لعام 2014 و المستهدف لعام 2050.

\begin{tabular}{|c|c|c|c|c|}
\hline \multicolumn{2}{|c|}{2050} & \multicolumn{2}{|c|}{2014} & \multirow{3}{*}{ البيان } \\
\hline$\%$ & الكمية (مليار & $\%$ & 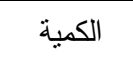 & \\
\hline الإجمالي & $\beta_{3}^{3}$ & الإجمالي & (مليار م³) & \\
\hline 100 & 89.2 & 100 & 76.0 & - جملة المو ارد المائية المُتّاحة: \\
\hline 62.11 & 55.4 & 73.03 & 55.5 & حصة مصر من مياه نهر النيل \\
\hline 13.45 & 12.0 & 8.82 & 6.7 & المياه الجوفية \\
\hline 20.74 & 18.5 & 16.32 & 12.4 & مياه الصرف الزر اعي و الصناعي والصحي المعالجة \\
\hline 1.68 & 1.5 & 1.71 & 1.3 & مياه الامطار \\
\hline 2.02 & 1.8 & 0.13 & 0.1 & تحلية مياه البحر \\
\hline 100 & 90.7 & 100 & 75.9 & - جملة الاستخدامات المائية: \\
\hline 74.97 & 68.0 & 82.02 & 62.25 & الزر اعة \\
\hline 15.66 & 14.2 & 13.11 & 9.95 & الثرب و الاستخدامات الصحية \\
\hline 6.62 & 6 & 1.58 & 1.2 & الصناعة \\
\hline 2.76 & 2.5 & 3.29 & 2.5 & الفاقد بالبخر من النيل و النرع \\
\hline
\end{tabular}

المصدر: 1 - الجهاز المركزي للتعبئة العامة و الإحصاء ، كتاب الإحصاء السنوي ، سبتمبر 2014. 2- وزارة المو ارد المائية والري ، مسودة إستر اتيجية الموارد المائية في مصر حتى عام 2050 ـ. 
ثانياً : روابط مستخدمي مياه الري : تعرف رابطة مستخدمي مياه الري على أنها منظمة خاصة (غير حكومية) ممثلة من الزراع

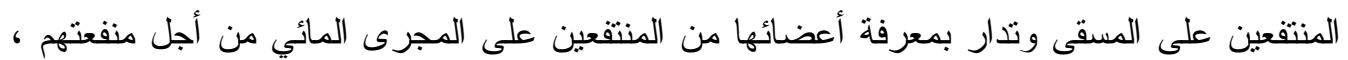

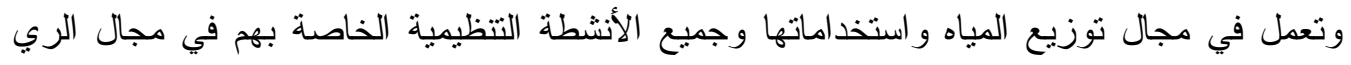
ولتحقيق إدارة أفضل لمياه الري من أجل رفع الانتاجية الزر اعية. و هناك أهداف محددة تلتزم بها هذه وله

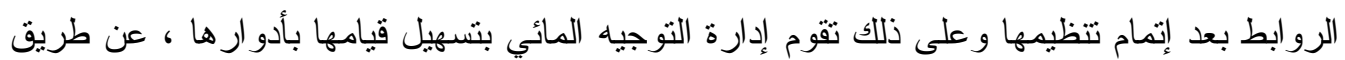

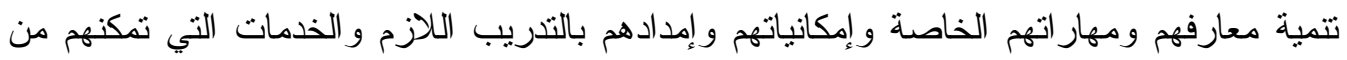

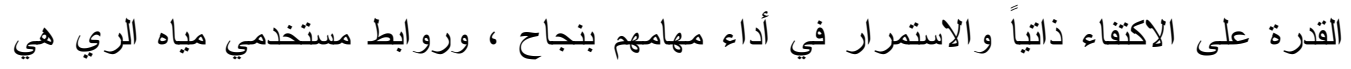

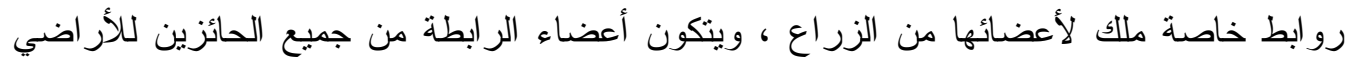

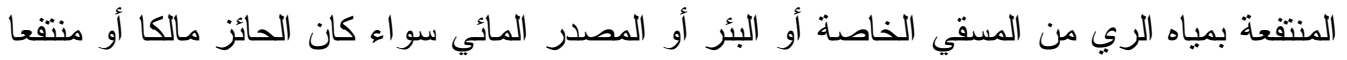

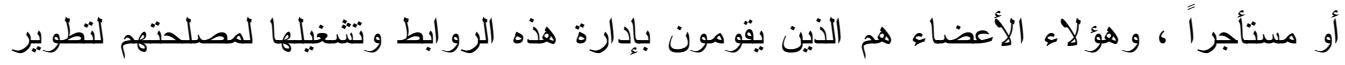

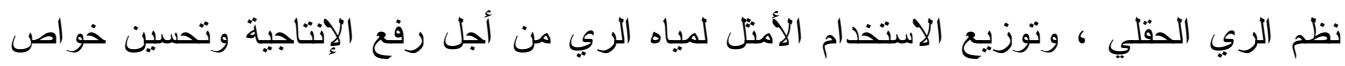
التزبة و الاقتصاد في استخدام مستلزمات الإنتاج. - التوزيع الجغرافي لروابط مستخدمي مياه الري في جمهورية مصر العربية : يوضح الجدول رقم (2) أن إجمالي عدد رو ابط مستخدمي مياه الري التي نم تكوينها حتى فئى

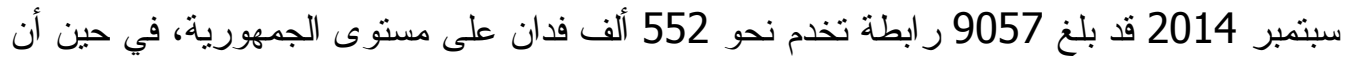

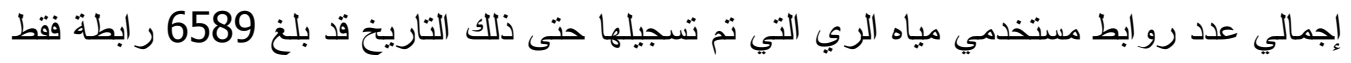

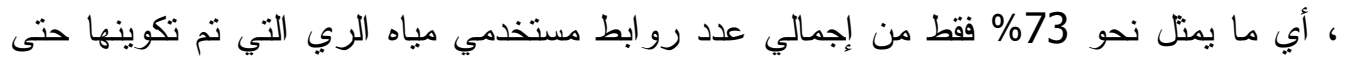

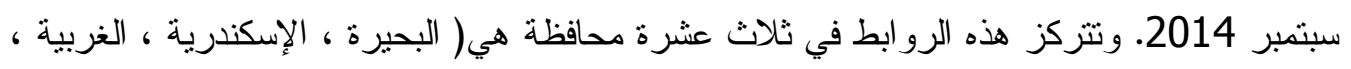

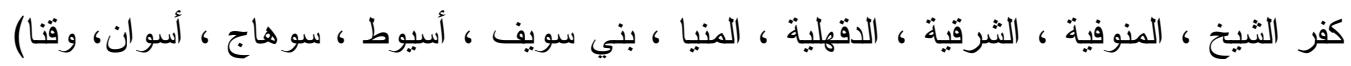

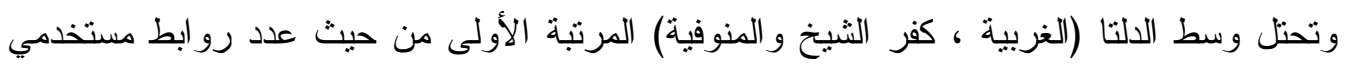
مياه الري التي تم تكوينها حتى سبتمبر 2014 ، وذذلك بإجمالي عدد رو ابط يبلغ 3346 ر رابطة تمثل نحو 36.9\% من إجمالي عدد الروابط ، وتخدم مساحة نحو 197.2 ألف فدان تمثل نحو من إجمالي المساحة المخدومة ، تليه محافظات غرب الدلتا (البحيرة و الإسكندرية )حيث يوجد التهد بهما عدد 2650 رابطة تمثل نحو 29.3\% من إجمالي عدد الرو ابط ، وتخدمان نحو 169.9 ألف فدان تمثل نحو 30.7\% من إجمالي المساحة المخدومة ، وتأتى محافظات مصر الوسطى (المنيا ، بني

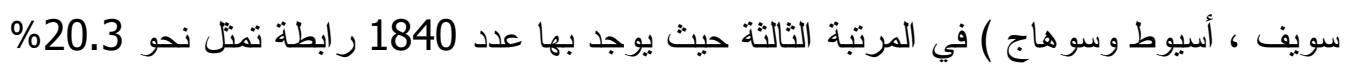

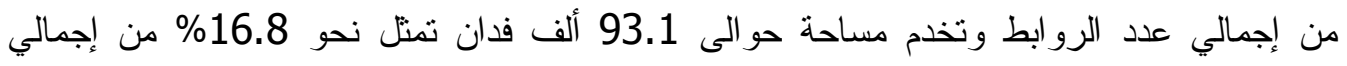

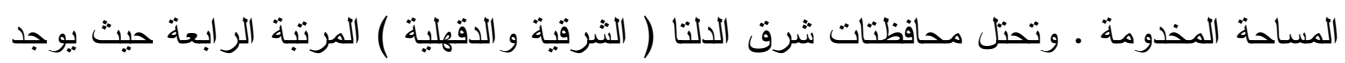
بهما عدد 932 رابطة تمثل نحو 10.3\% من إجمالي عدد الرو ابط ، وتخدمان نحو 65.2 ألف فدان تمنل نحو 11.8\% من إجمالي المساحة المخدومة ، في حين تحتل محافظات (أسوان وقنا) المرتبة

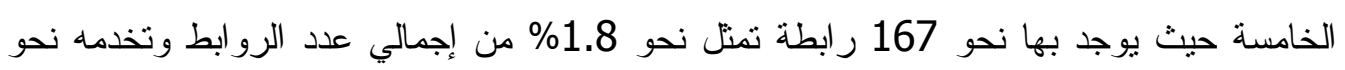
15.9 ألف فدان تمتل نحو 2.9\% من إجمالي المساحة المخدومة. أما عدد روابط مستخدمي مياه 
الري التي تم تكوينها بتمويل من صندوق مشروعات تطوير وصيانة المساقي فقد بلغ 122 ر رابطة تمنل نحو 1.3\% من إجمالي عدد الروابط ، وتخدمان نحو 11.3 ألف فدان تمنل نحو 2.0\% من إجمالي المساحة المخدومة ، ويتضح مما سبق تركز روابط مستخدمي مياه الري في محافظات الغربية ، كفر الثيخ ، المنوفية ، البحيرة ، الإسكندرية بالوجة البحرى ، و المنيا ، بني سويف ،

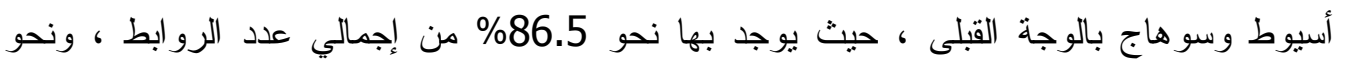
83.3 من إجمالي المساحة المخدومة على مستوى الجمهورية . جدول (2) : التوزيع الجغر افي لرو ابط مستخدمي مياه الري التي تم تكوينها و تسجيلها

\begin{tabular}{|c|c|c|c|c|c|c|}
\hline$\%$ & مدياه & $\%$ & الخدمام & $\%$ & عستخدمي مياه & المحافظات \\
\hline 30.5 & 2011 & 30.7 & 169875 & 29.3 & 2650 & البحيرة - الاسكندرية \\
\hline 31.3 & 2062 & 35.7 & 197186 & 36.9 & 3346 & الغربية - كفر الثيخ - المنوفية \\
\hline 8.7 & 573 & 11.8 & 65155 & 10.3 & 932 & الثرقية - الدقهلية \\
\hline 27.4 & 1807 & 16.8 & 93064 & 20.3 & 1840 & المنيا - بني سويف - أسيوط - سوهاج \\
\hline 0.9 & 61 & 2.9 & 15908 & 1.8 & 167 & أسو ان - قنا \\
\hline 1.1 & 75 & 2.0 & 11295 & 1.3 & 122 & مساقي ممولة من صندوق مشروعات تطوير \\
\hline 100 & 6589 & 100 & 552483 & 100 & 9057 & الإجمالي \\
\hline
\end{tabular}

المصدر: جُمعت وحُسبت من بيانات الملحق رقم (1). نتائج البحث

المؤشرات الإقتصادية لمحصول الذرة الشامية الصيفى بمحافظة البحيرة : 1 - أثر الإنضمام لروابط مستخدمى المياه على التكاليف الكلية وصافى العائد لقدان محصول الأرة الثامية بعينة الار اسة : الاسمام لرواطن

يتبين من الجدول رقم (3) إن متوسط إنتاجية الفدان من محصول الذرة الثامية الصيفي بلغ نحو 14.6 أردب/فدان قبل الانضمام الى روابط مستخدمي مياه الري ، فئ حين بلغ النغ

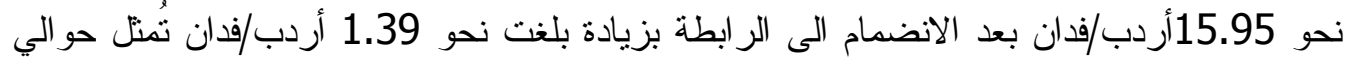

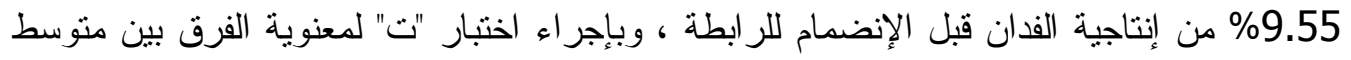
إنتاجية الفدان من محصول الذرة الثامية الصيفي بعد وقبل الانضمام الى الر ابطة تنين معنوية هذا لإناه الفرق عند مستوى 0.01 ، وبلغ متوسط التكاليف الكلية للفدان حوالى 4.6 الف جنيه/فدان قبل الفيل الانضمام الى الرابطة ، وبلغ حوالى 4.5 الف جنيه/فدان بعد الإنضمام الى الرابطة بوفرة في فئ التكاليف بلغت حوالى 153.1 جنيه/الفدان تمنل نحو 3.3\% من منوسط التكاليف الكلية قبل التبل الإنضمام للر ابطة ، ولم تتبت المعنوية الإحصائية لمتوسط التكاليف الكلية ، فى حين بلغ متوسط تكلفة 
الرية الواحدة للفدان حوالى 43.8 جنيه/فدان قبل الانضمام الى الر ابطة ، وبلغ حوالى 22جنيه/فدان

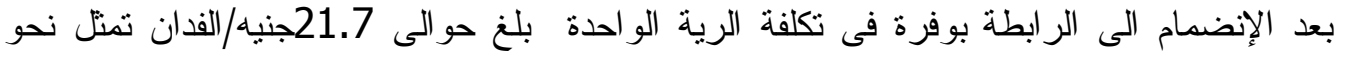

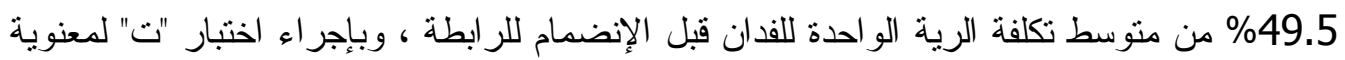

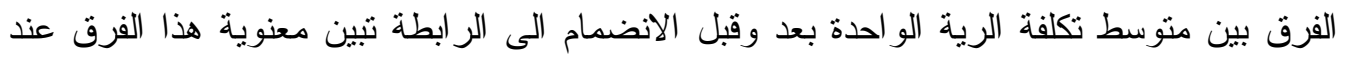

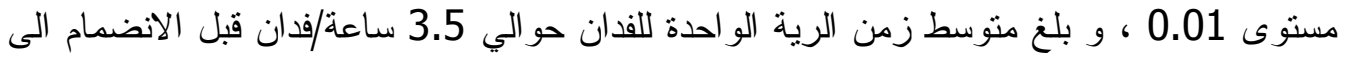

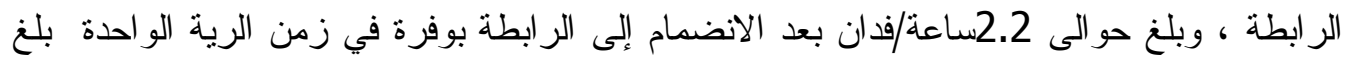

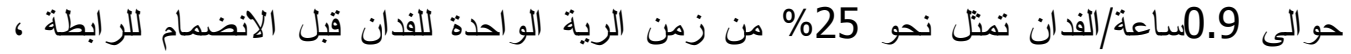

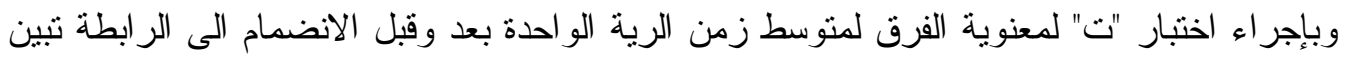

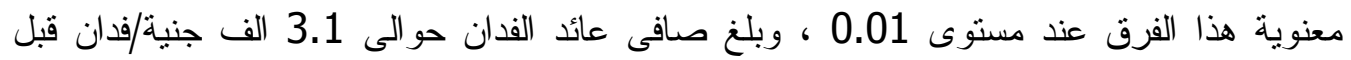

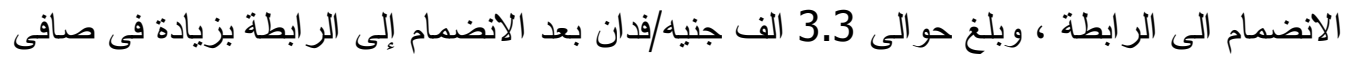

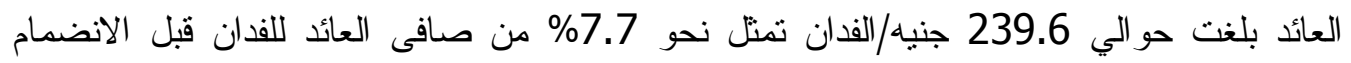

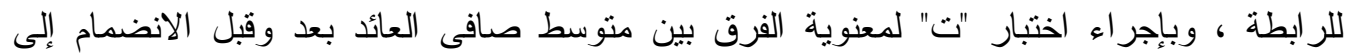

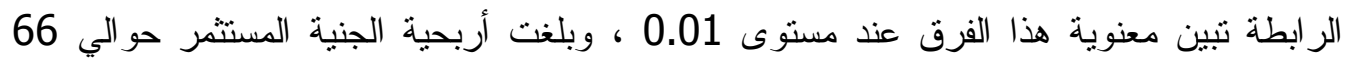

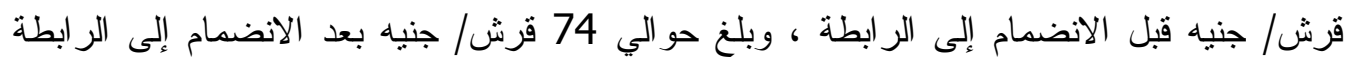

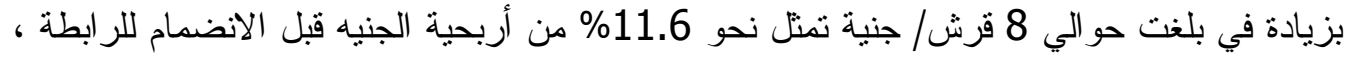

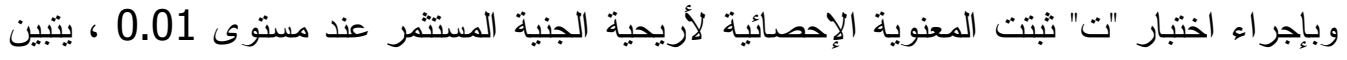

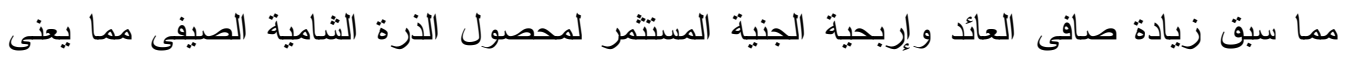
إرتفاع كفاءة الآداء الاقتصادى لإنتاج محصول الذرة الثامية الصيفى بمحافظة البحيرة بعد الإنضمام

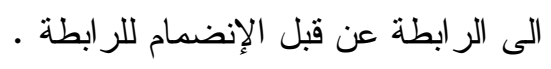

جدول (3) التكاليف وصافى العائد الفدانى لمحصول الذرة الثنامية الصيفى بعينة الدراسة لموسم 2014/2013.

\begin{tabular}{|c|c|c|c|c|c|}
\hline \multirow{2}{*}{ قلمقدة "ت" } & \multicolumn{2}{|c|}{ 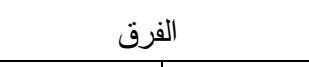 } & \multirow{2}{*}{ بعد تكوين } & \multirow{2}{*}{ لكوين } & \multirow[t]{2}{*}{ 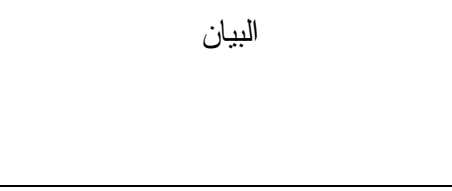 } \\
\hline & $\%$ & المقدار & & & \\
\hline$* *(7)$ & 9.55 & 1.39 & 15.95 & 14.56 & الإنتاجية/الفدانية (أردب / الفدان) \\
\hline$(1.4)$ & (3.3) & $(153.1)$ & 4518.94 & 4672 & التكاليف الكلية (جنيه / الفدان) \\
\hline$* * 19.96$ & $(49.49)$ & $(21.66)$ & 22.11 & 43.77 & تكلفة الرية الو احدة (جنيه / الفدان) \\
\hline$* 5.647$ & $(25.00)$ & $(0.87)$ & 2.61 & 3.48 & متوسط زمن الرية الو احدة (ساعة/فدان) \\
\hline$* * 4.6$ & $(7.73)$ & $(239.6)$ & 3337.6 & 3098 & صافى العائد (جنيه / الفدان) \\
\hline$* * 55$ & 11.6 & 0.07 & 0.74 & 0.66 & |أربحية الجنيه (1) \\
\hline
\end{tabular}

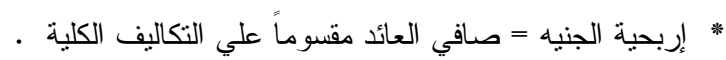
المصدر : جُمتت وحُسبت من بيانات العينة الخاصة بالدر اسة. 
2- الوفر فى مساحة وإنتاج وتكاليف رى محصول الذرة الشامية نتيجة للإضمام لروابط

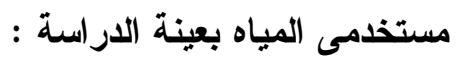

ويوضح الجدول رقم (4) أنة نتيجة زيادة الإنتاج من محصول الذرة الثنامية الصيفى بمحافظة البحيرة من نحو2703.8 الف أردب قبل الإنضمام الى روابط مستخدمى المياه الى زئى نحو 2961.9 ألف أردب بعد الإنضمام الى روابط مستخدمى المياه بالمحافظة بزيادة بلغت نحو

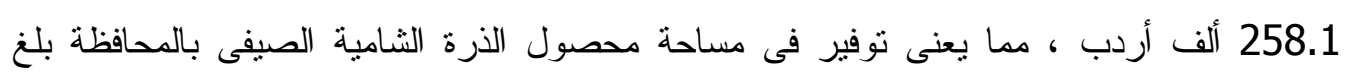

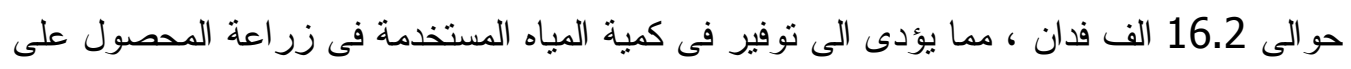

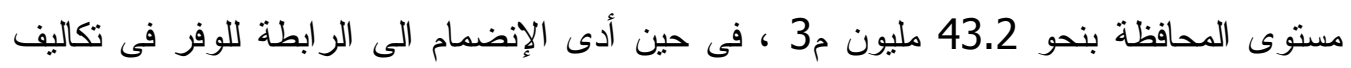

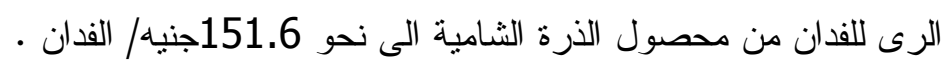

جدول(4) : مقدار الوفرفى المساحة و كمية المياهوتكاليف الإنتاج لمحصول الذرة الثامية الصيفى بمحافظة البحيرة لموسم 2014/2013.

\begin{tabular}{|c|c|}
\hline 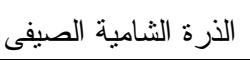 & البيان \\
\hline 185.7 & إجمالى المساحة المزروعة (الف فدان) \\
\hline 2703.8 & إجمالى الإنتاج قبل تكوين الر ابطة (الف أردب) \\
\hline 2961.9 & إجمالى الإنتاج بعد تكوين الرابطة (الف أردب) \\
\hline 258.1 & الزيادة فى الأنتاج نتيجة الإنضمام الى الر ابطة (الف أردب) \\
\hline 16.2 & المساحة التى يمكن توفير ها(الف فدان) \\
\hline 2670.0 & المقنن المائى لمحصول الذرة الثنامية الصيفى (م3 / فدان ) \\
\hline 43.2 & كمية المياه التى يمكن توفير ها (مليون م3) \\
\hline 151.6 & الوفر في تكاليف الرى (جنيد/فدان) \\
\hline
\end{tabular}

* المساحة التى يمكن توفير ها = فرق الزيادة فى الإنتاج ؛ منوسط الإنتاجية الفدانية . * كمية المياه التى يمكن نوفير ها = المساحة التى يمكن نتفير ها × المقنن المائى .

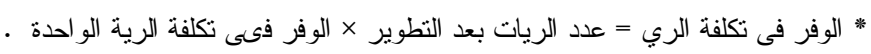

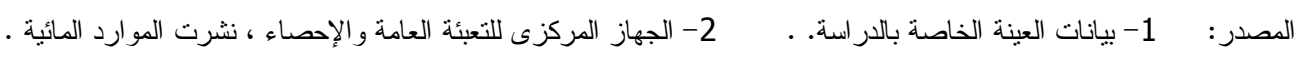
2- وزارة الزر اعة واستصلاح الأراضى ، قطاع الثئون الاقتصادية ، نشرة الاقتصاد الزر اعى لاعل 2013.

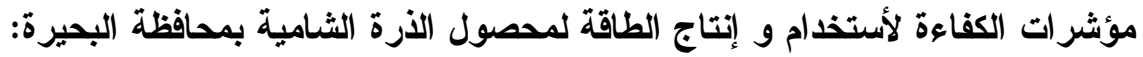
الطاقة المستخدمة لرى محصول الأرة الثامية لمستخدمى روابط المياه بمحافظة البحيرة :

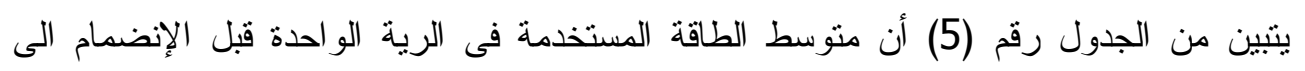

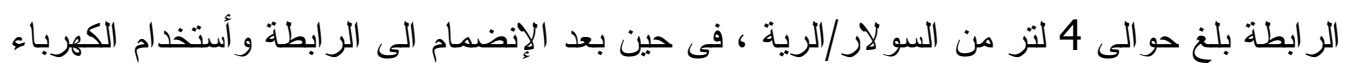

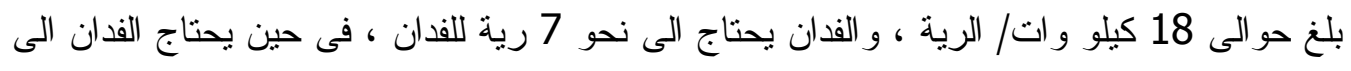

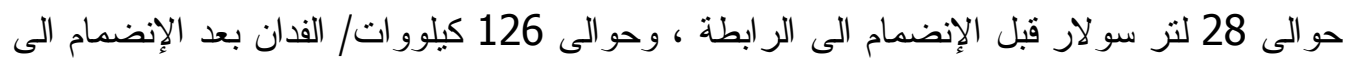

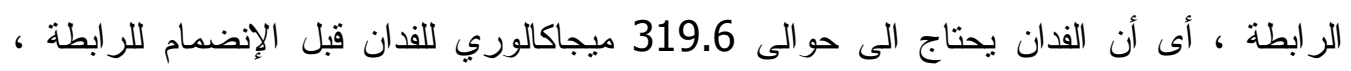

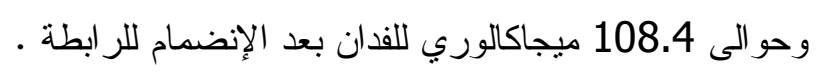


جدول (5) : الطاقة المستخدمة لرى محصول الذرة الثشامية لمستخدمى روابط المياه بمحافظة

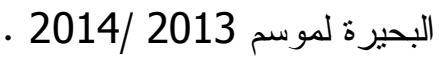

\begin{tabular}{|c|c|c|}
\hline الإنضمام للر ابطة الكهرباء المستخدة بعد & الطاقة المستخدمة قبل الإنضمام & 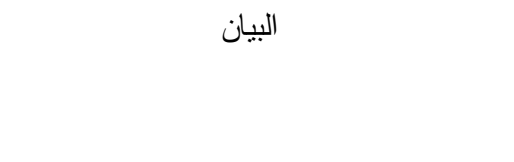 \\
\hline 18 & 4 & كمية الطاقة المستخدمة للرية الو احدة \\
\hline 7 & 7 & متوسط عدد الريات للفدان \\
\hline 126 & 28 & كمية الطاقة المستخدمة للفدان \\
\hline 108.4 & 319.6 & كمية الطاقة المستخدمة للفدان بالميجاكالوري \\
\hline & 2- الكيلووات = 0.86 ميجاكالوري & " - كمية الطاقة المستخذمة للفدان بالميجاكالوري : 11.414 ميجاكالوري، \\
\hline
\end{tabular}

- المؤشرات الإقتصادية والقنية لطاقة تثغيل ألة الري لمحصول الذرة الثامية بمحافظة البحيرة :

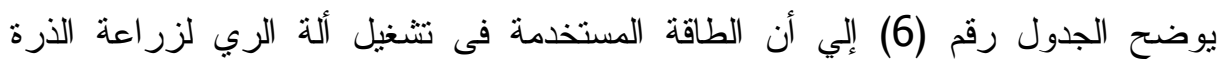
الثامية الصيفى بمحافظة البحيرة تتمنل فى السو لار قبل الإنضمام الى رابطة مستخدمى مياه الرى ، و الكهرباء بعد الإنضمام الى رابطة مستخدمى مياه الرى ، في الوقت الذي يتفقان في أن مصدر مياه الري من نهر النيل وفروعه ، كما أن القوة الميكانيكية لألة الرى في حدود 16 حصان النيان ميكانيكي ،

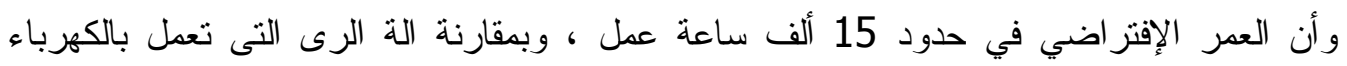

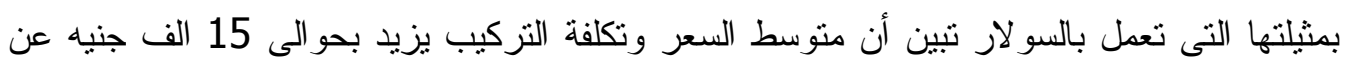

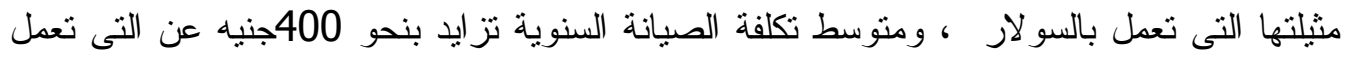

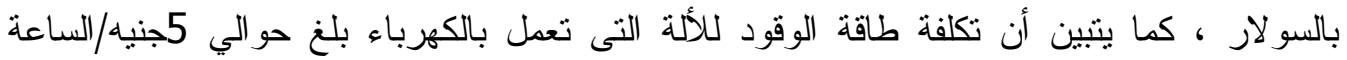

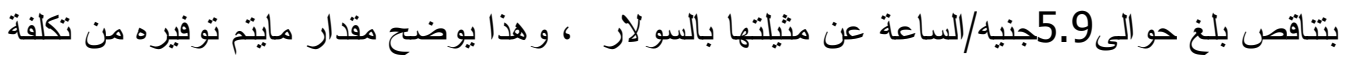
طاقة التشغيل لآلات الري في حالة استخدام الكهرباء مقارنة بالسولار ، وبالنسبة لتكلفة إهلاك آلة آلة

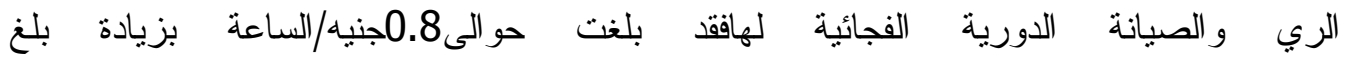
حو الى10.25جنيه/الساعة عن مثيلتها بالسو لار ، و علي ذلك بمكن القول أن بنود التكاليف السابقة من

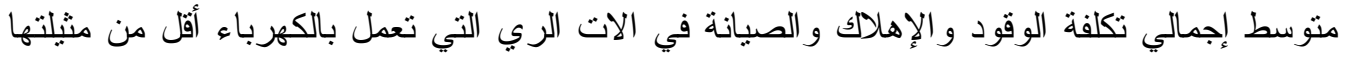
التي تعمل بالسو لار بحو الي 4.5جنيه/الساعة ، وبالنسبة للطاقة فقد بلغ منوسط تكلفة وحدة الطاقة

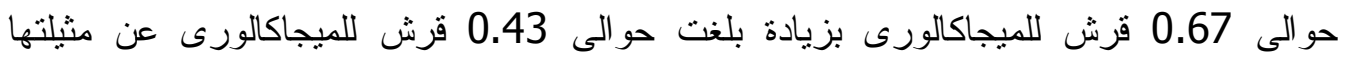

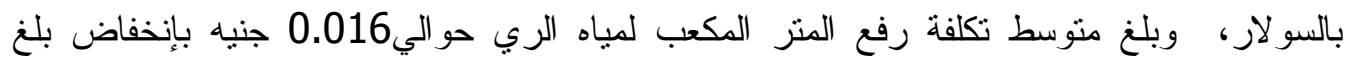
حوالي0100.010 بنيه عن مثيلتها التي تعمل بالسولار، وبلغ متوسط الطاقة اللازمة لرفع منز مكعب

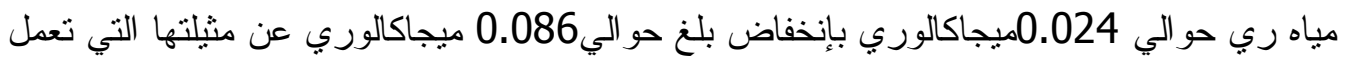

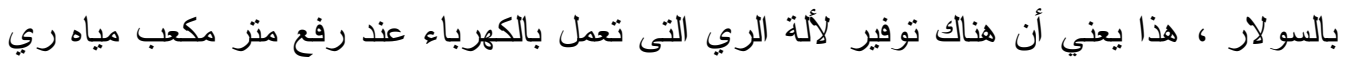

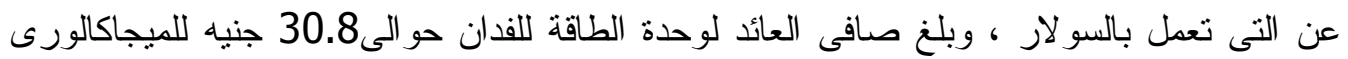
بعد الإنضمام الى الر ابطة بزيادة بلغت نحو 21.2 جنيه للميجا كالورى • يتضح مما سبق وعلي 
ضو ء مؤشر ات الكفاءة الاقتصادية و الفنية ، يتضح أن آلات الري التي تعمل بالكهرباء أعلي كفاءة مقارنة بمثنلتها التي تعمل بالسو لار . جدول(6): مؤشر ات الكفاءة الاقتصادية و الفنية لطاقة تشغيل آلة الري لمحصول الذرة الثامية الصيفى بعينة الدر اسة الميدانية بمحافظةالبحيرة خلال الموسم الزر اعي 2014/2013.

\begin{tabular}{|c|c|c|}
\hline 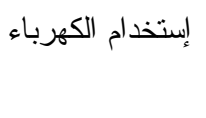 & الستخد لار & مصدر طاقة التشغيل \\
\hline \multicolumn{3}{|r|}{ المتغيرات الإقتصادية } \\
\hline 16 & 16 & 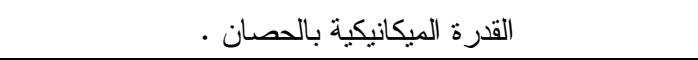 \\
\hline 15 & 15 & منوسط العمر الإفتزر اضي بالألف ساعة عمل . \\
\hline 30 & 15 & منوسط السعر وتكلفة التزكيب بالألف جنيه . م \\
\hline 700 & 300 & متوسط تكلفة الصيانة السنوية الدورية و الفجائية بالجنيه. \\
\hline 12 كيلووات & 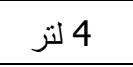 & متوسط استهلاك الوقود / وحدة / ساعة . م \\
\hline 22 & 250 & متوسط سعر وحدة الوقود بالقرش \\
\hline 0.14 & 0.165 & متوسط استهلاك الزيوت و الثحومات باللتز . \\
\hline 300 & 300 & متوسط سعر اللثر من الزيوت والثحوم بالقرش \\
\hline \multicolumn{3}{|r|}{ | التكاليف } \\
\hline 4.6 & 10.5 & تكلفة طاقة الوقود (جنيه/ساعة) . \\
\hline 1.6 & 0.4 & تكلفة الإهلاك للآلة بالجنيه /ساعة (1) \\
\hline 0.75 & 0.5 & متوسط تكلفة الصيانة الدورية و الفجائية (جنيه/ساعة) \\
\hline 6.95 & 11.4 & منوسط إجمالي تكلفة الوقود و الإهلاك و الصبانة (جنيد/ساعة) \\
\hline \multicolumn{3}{|r|}{ الطاقة } \\
\hline 10.4 & 47.5 & إجمالي طاقة النتخيل المستخدمة بالميجاكالوري/ساعة \\
\hline 0.668 & 0.240 & متوسط تكلفة وحدة الطاقة (قرش/ميجاكالوري)(2) \\
\hline \multicolumn{3}{|r|}{ 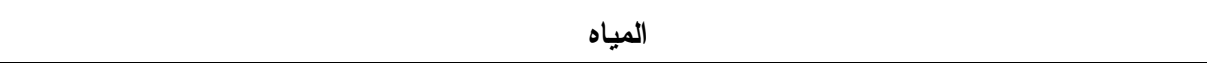 } \\
\hline 430 & 430 & - تصرف آلة الري (مترمكعب /ساعة). (3) \\
\hline 0.016 & 0.027 & - متوسط تكلفة رفع المباه(جنبه /33)(4) \\
\hline 0.024 & 0.110 & - منوسط الطاقة اللازمة لرفع مقمن المياه(ميجاكالوري)(5) \\
\hline 30.8 & 9.60 & - العائد الصافي علي وحدة الطاقة ميجاكالوري (6) \\
\hline
\end{tabular}

(1) تكلفة الإهلاك للآلة = الفرق بين( سعر الشراء - سعر البيع ) / العمر الإفتراضى . (2) متوسط تكلفة وحدة الطاقة = إجمالي التكاليف ٪ إجمالي طاقة التثغيل بالميجاكالوري.

(3) تصريف الألة : حسبت علي ضوء القوة الميكانيكية لماكينة الري بالحصان .

(4) منوسط تكلفة الرى = إجمالي التكاليف † تصرف آلة الري بالمتز المكعب .

(5) متوسط الطاقة اللازمة لرفع م3من المياه(ميجاكالوري) = إجمالي طاقة التثغيل بالميجاكالوري تصرف آلة الري بالمتر المكعب. (6) العائد الصافى على وحدة الطاقة ميجاكالورى = صافي العائد للفدان بالجنيه مقسوماً علي جملة الطاقة المستخدمة بالميجاكالوري. 
مميزات الاضمام الى روابط مستخدمي مياه الري من وجهة نظر الزراع بعينة الاراسة :

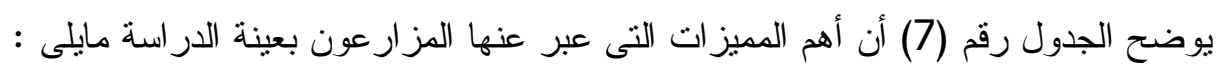

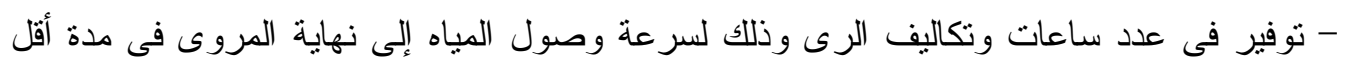

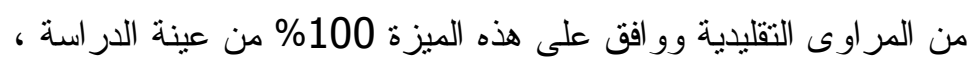

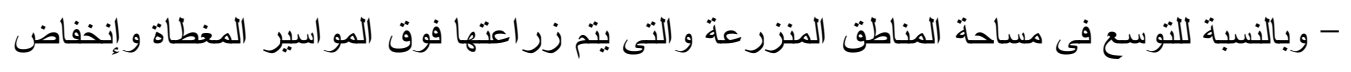

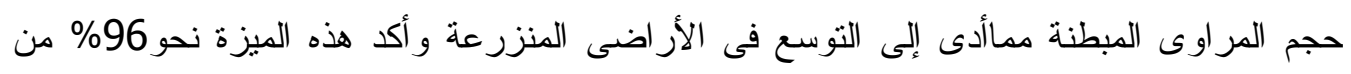

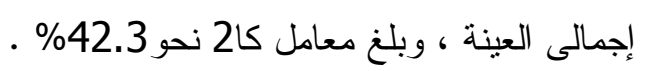

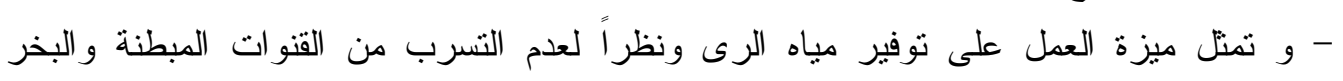

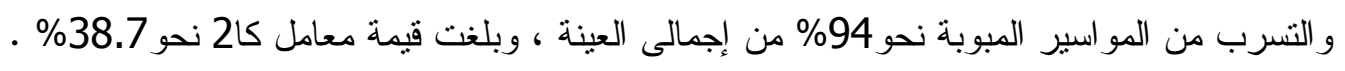

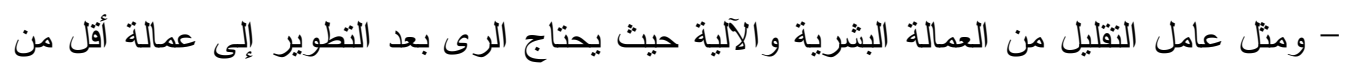

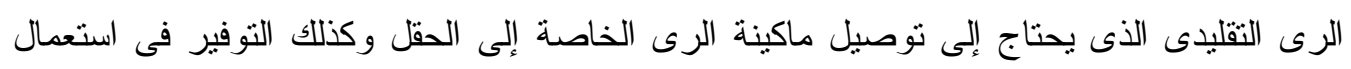

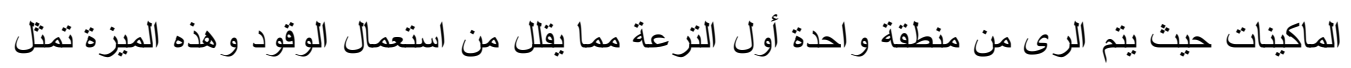

$$
\text { نحو 84\% من إجمالى العينة . }
$$

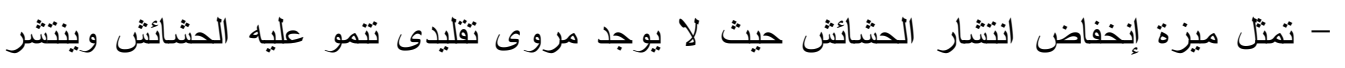

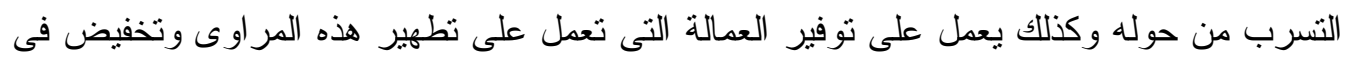

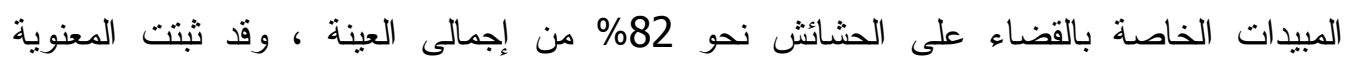

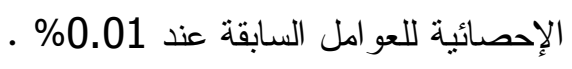

- وبالنسبة للمساعدة فى توفير الوقود وذلك لتحول عمل الماكينات للعمل بالكهرباء وعمل ماكينات

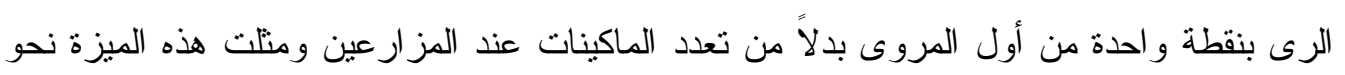

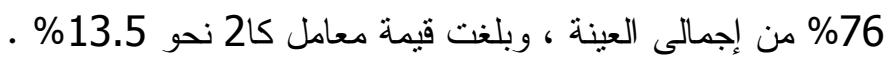

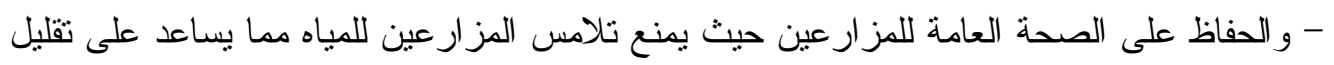
الاصابة بمرض البلهارسيا الذى يتسبب فى امر اض عديدة للمز ارعين وتمتلك هذه الميزة نحو

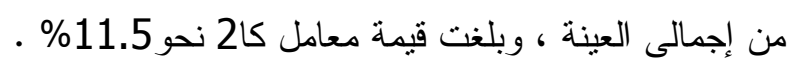

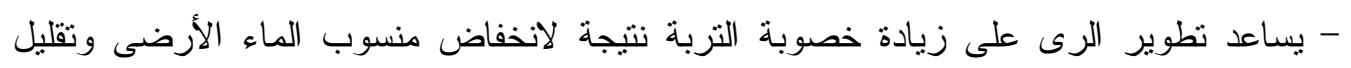

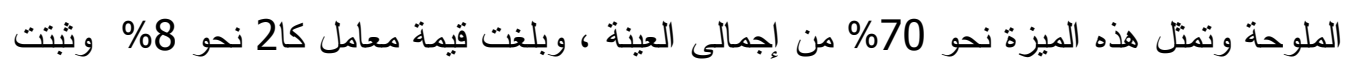

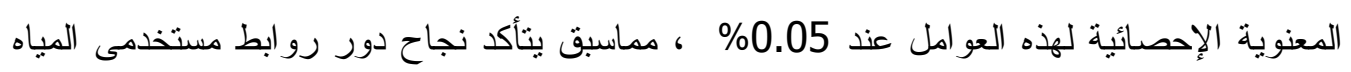

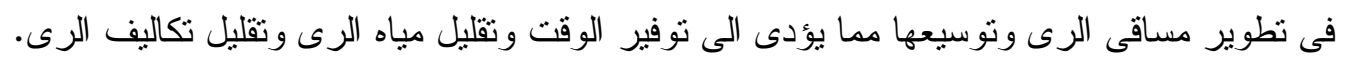


جدول (7): إختبار المعنوية لمميزات الانضمام الى روابط مستخدمي مياه الري بإستخدام مربع كا2 لإفر ادعينة الدر اسة بمحافظة البحيرة لموسم 2013-2014.

\begin{tabular}{|c|c|c|c|c|}
\hline كان & الأهمية - م النسبة & 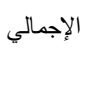 & المميزات & المسلسل \\
\hline$* * 50.0$ & 100 & 50 & التوفير فى عدد ساعات وتكاليف الرى لوصول الماء لنهاية المروى فى مدة أقل . & 1 \\
\hline$* 42.3$ & 96 & 48 & 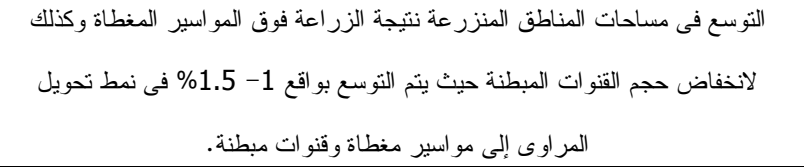 & 2 \\
\hline$* * 38.7$ & 94 & 47 & العمل على توفير فى مياه الرى من 15-20\% لعدم البخر و التنسرب . & 3 \\
\hline$* * 23$ & 84 & 42 & تقليل فى العمالة البشرية و الآلية . & 4 \\
\hline$* 20.5$ & 82 & 41 & 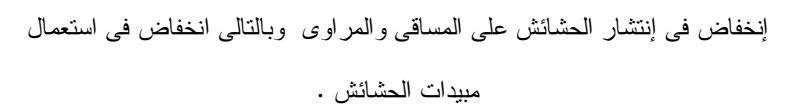 & 5 \\
\hline$* 13.5$ & 76 & 38 & المساعدة فى توفير الوقود نتيجة لتحول الماكينات إلى العمل بالكهرباء وكذللك للعمل & 6 \\
\hline$* 11.5$ & 74 & 37 & الحفاظ على الصحة العامة للمز ارعين وبالأخص من مرض البلهارسيا . & 7 \\
\hline$* 8.0$ & 70 & 35 & بساعد على زيادة خصوبة التربة نتيجة لانخفاض منسوب الماء الأرضى وتقليل الملوحة . & 8 \\
\hline
\end{tabular}

المصدر : جمعت وحُبت من بيانات العينة الخاصة بالدر سلة.

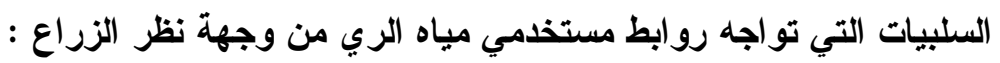

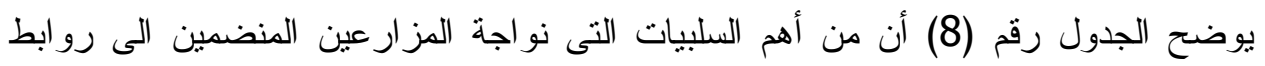
مستخدمى المياه بمحافظة البحيرة و التى تتمنل فى إرتفاع تكاليف إنشاء التطوير وبلغت نحو

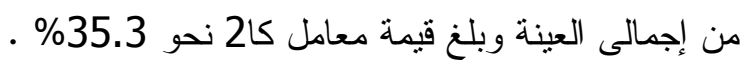

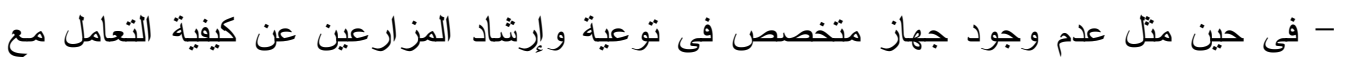
النظام الجديد لنطوير الرى من حيث نظام تشغيل المحابس وصيانتها وكيفية الحفاظ عليها نحو 78 من إجمالى العينة وبلغ قيمة معامل كا2 نحو 15.7\% وثبتت المعنوية الإحصائية لهذة العوامل السابقة عند 0.01\% على الترتيب . - و بالنسبة لإخطاء كثوف المز ارعين من حيث المساحة و بالتالي أخطاء في تقدير التطوير بلغت

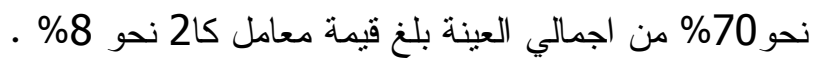

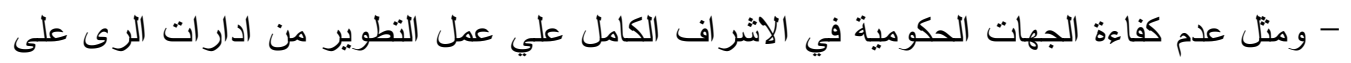
صيانة المشروع وماكينات رفع المياه فهي تمنل نحو 44\% من إجمالى العينة وبلغ قيمة معامل كاعل

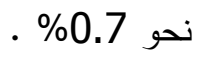
- ومثل قلة منسوب المياه بلغت نحو 54\% من إجمالي العينة وبلغ قيمة معامل كا2 نحو 0.3\% . 
- وبالنسبة لعدم صدور قانون لتتظيم أعمال روابط مستخدمى المياه على الترع الفرعية بلغت

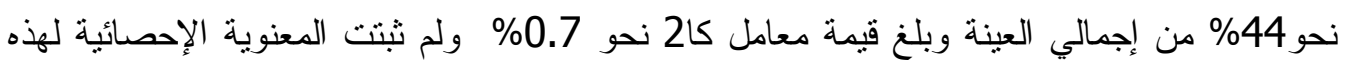

$$
\text { السلبيات . نهو }
$$

- وبالنسبة لضعف الاتصال بين إدارة التوجيه المائى وأعضاء الروابط بلغ نحو 38\% من إجمالي العينة وبلغ قيمة معامل كا2 نحو 2.9\% .

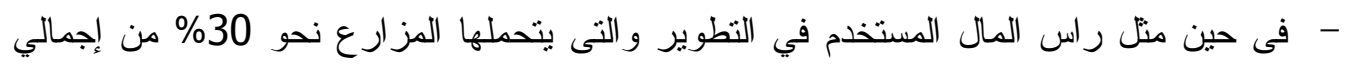

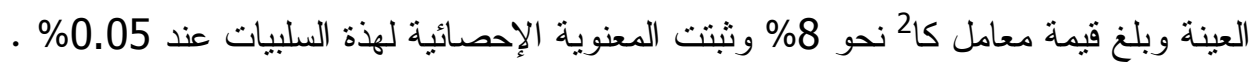
جدول (8): إختبار المعنوية للسلبيات النى تو اجة رو ابط مستخدمي مياه الري بإستخدام مربع كا2 لإِفر ادعينة الدر اسة بمحافظة البحيرة لموسم (2014-2013)

\begin{tabular}{|c|c|c|c|c|}
\hline كا2 & 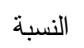 & 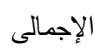 & 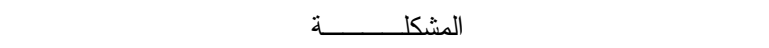 & 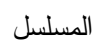 \\
\hline$* 35.3$ & 92 & 46 & ارتفاع تكاليف اثشاء التطوير & 1 \\
\hline ***15 15.7 & 78 & 39 & عدم وجود جهاز متخصص فى توعية وإرشاد المزارعين عن كيفية التعامل & 2 \\
\hline$* 8.0$ & 70 & 35 & أخطاء في كثوف المزارعين من حيث المساحة و بالتالي أخطاء في تقدير & 3 \\
\hline 0.7 & 44 & 22 & عدم كفاءة الجهات الحكومية في الاشر اف الكامل علي عمل النطوير من & 4 \\
\hline 0.3 & 54 & 27 & قلة منسوب المياه & 5 \\
\hline 0.7 & 44 & 22 & عدم صدور قانون لتتظيم أعمال روابط مستخدمى المياه على التزع الفرعية. & 6 \\
\hline$* 2.9$ & 38 & 19 & ضعف الاتصـال بين إدارة التوجيه المائى و أعضاء الرو ابط. & 7 \\
\hline$* 8.0$ & 30 & 15 & راس المال المستخدم في التطوير تقع علي المزارع و هو الذي يتحمل ذلك & 8 \\
\hline
\end{tabular}

\section{المر اجع}

1- أحمد أبو اليزيد عبد الرسول و آخرون ، دراسة تحليلية لدور روابط مستخدمى مياه الرى فى

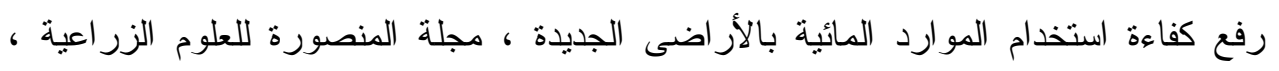
المجلد الثالث و العشرون ، ديسمبر 1998. 2- أحمد قدرى مختار محمد بهلول : السياسة المائية والامن الغذائى المصرى، قدم الاقتصاد

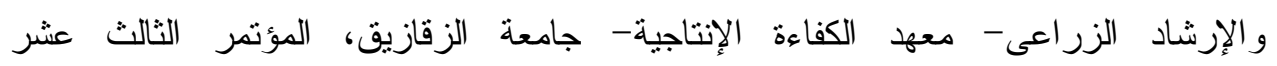
للاقتصاديين الزر اعيين، 28-29 سبتمبر 2005. 
3- أسامة أحمد البهنساوى و آخرون ، دراسة اقتصادية لدور جمعيات مستخدمى المياه فى رفع

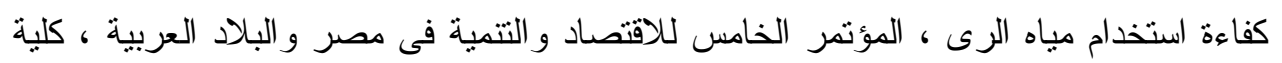

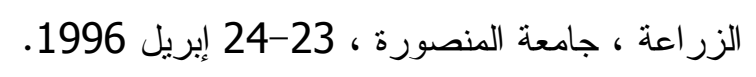

4- الجهاز المركزي للتعبئة العامة والإحصاء، نشرة الموارد المائية و الري، أعداء العداد مختلفة.

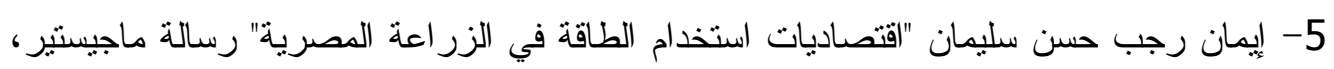
قسم الاقتصاد الزر اعي ، كلية الزر اعة ، جامعة الزقازيق 2010.

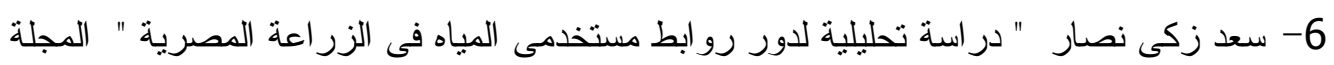
المصرية للإقتصاد الزر اعى، المجلد العشرون ، العدد الثانى ، يونية 2010.

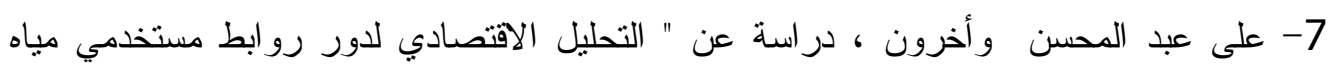

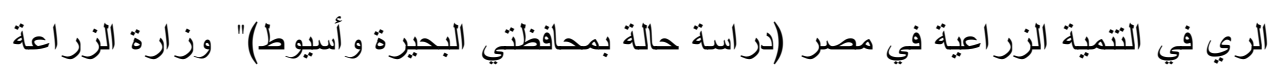

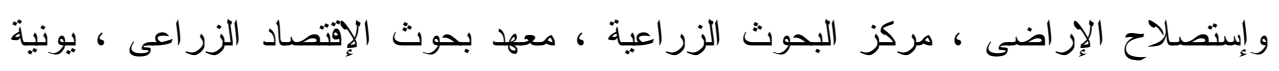

8- فرج علي فرج فوده " در اسة اقتصادية لترشيد استخدام مياه الري في جمهورية مصر العربية " رسالة دكتور اه ، قسم الاقتصاد الزر اعي ، كلية الزر اعة ، جامعة عين شمس داهئ ، 1981. 9ttp://irrdep.com/default_ar.aspx . موقع مصلحة الري على شبكة المعلومات الدولين ،

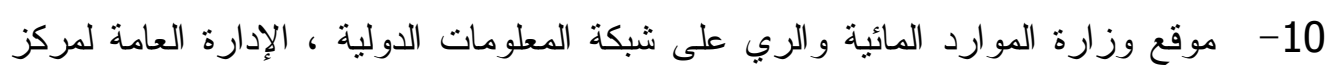

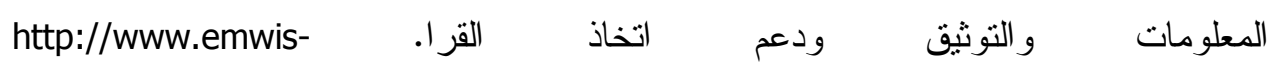
eg.org/arabic/documentation\%20-1\%20-\%203.htm 11- المو ارد المائية و الري، قطاع تطوير الري ، بيانات غير منشورة. 


\begin{tabular}{|c|c|c|c|c|c|c|c|c|}
\hline \multicolumn{3}{|c|}{ عدد الرو ابط التي تم تسجيلها } & \multirow[b]{2}{*}{ (فدان) } & \multirow[b]{2}{*}{ التكوينها } & \multirow[b]{2}{*}{ الجهة المنفذة } & \multirow[b]{2}{*}{ التر عة/المنطقة } & \multirow[b]{2}{*}{ E } & \multirow[b]{2}{*}{$=\frac{E}{\underline{E}}$} \\
\hline حتى تاريخه & خلال الشهر & لنهاية الشهر & & & & & & \\
\hline 98 & 0 & 98 & 7016 & 109 & المشروع الر ائد لتطوير الري & ابلبلططر - دمنهور & & \\
\hline 1203 & 0 & 1203 & 97673 & 1344 & | مشروع تطوير الري (المرحلة الأولى) & & & $E$ E \\
\hline
\end{tabular}




\begin{tabular}{|c|c|c|c|c|c|c|c|c|}
\hline 263 & 0 & 263 & 24780 & 469 & 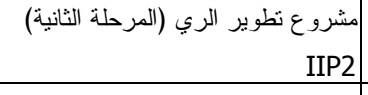 & |دمنهور & & \\
\hline 447 & 0 & 447 & 40406 & 728 & 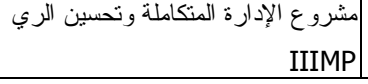 & |دمنهور & & \\
\hline 2011 & 0 & 2011 & 169875 & 2650 & & الإجمالي & & \\
\hline 45 & 0 & 45 & 6256 & 80 & |الهشروع الر ائد لتطوير الري & |القهوجي - طنطا & \multirow{11}{*}{ 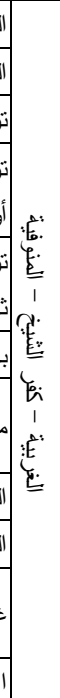 } & \multirow{11}{*}{$\frac{E}{E}$} \\
\hline 139 & 0 & 139 & 17437 & 300 & |المشروع الر ائد لتطوير الري & |البحر الصعيدي - كفر الشيخ & & \\
\hline 0 & 0 & 0 & 18093 & 279 & 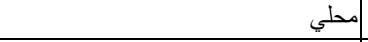 & ترعة العطف & & \\
\hline 0 & 0 & 0 & 1445 & 23 & 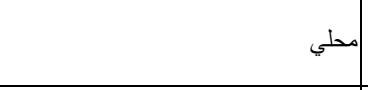 & |ترعة العطف (استكمال مرحلة & & \\
\hline 0 & 0 & 0 & 1090 & 15 & 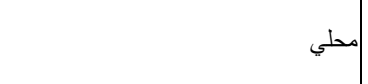 & تُنانية) & & \\
\hline 66 & 0 & 66 & 3457 & 66 & & بحر النور - طنطا & & \\
\hline 44 & 0 & 44 & 5805 & 103 & 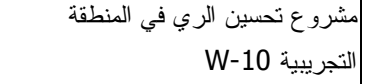 & |منطقة تجريية - كفر الثيخ & & \\
\hline 812 & 0 & 812 & 55543 & 908 & |البنك الدولي & |الوسط - كفر الشيخ & & \\
\hline 573 & 0 & 573 & 36922 & 605 & |البنك الدولي & |المنايفة - كفر الثيخ & & \\
\hline 383 & 0 & 383 & 51138 & 949 & 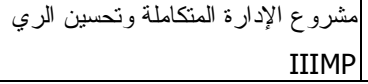 & غرب المحلة & & \\
\hline 2062 & 0 & 2062 & 197186 & 3346 & & | الإجمالي & & \\
\hline 71 & 0 & 71 & 6658 & 98 & |المشروع الر ائد لتطوير الري & |السعيدية (1) - الزقازيق & \multirow{6}{*}{ 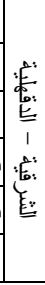 } & \multirow{6}{*}{$\begin{array}{l}\text { EE } \\
\text { E. } \\
\text { E: }\end{array}$} \\
\hline 206 & 0 & 206 & 16060 & 236 & |المشروع الر ائد لتطوير الري & |السعيدية (2) - الزقازيق & & \\
\hline 127 & 0 & 127 & 18468 & 219 & المشروع الر ائد لتطوير الري & السعيدية (3) - الزقازيق & & \\
\hline 137 & 0 & 137 & 11910 & 155 & & ترعة البو هية (1) - الزقازيق & & \\
\hline 32 & 0 & 32 & 12059 & 224 & & ترعة البو هية (2) - الزقازيق & & \\
\hline 573 & 0 & 573 & 65155 & 932 & & | الإجمالي & & \\
\hline
\end{tabular}

الملحق رقم (1): بيان تفصيلي بموقف روابط المساقي المطورة حتى سبتمبر 2014 
تابع/ ملحق رقم (1): بيان تفصيلي بموقف رو ابط المساقي المطورة حتى سبتمبر 2014

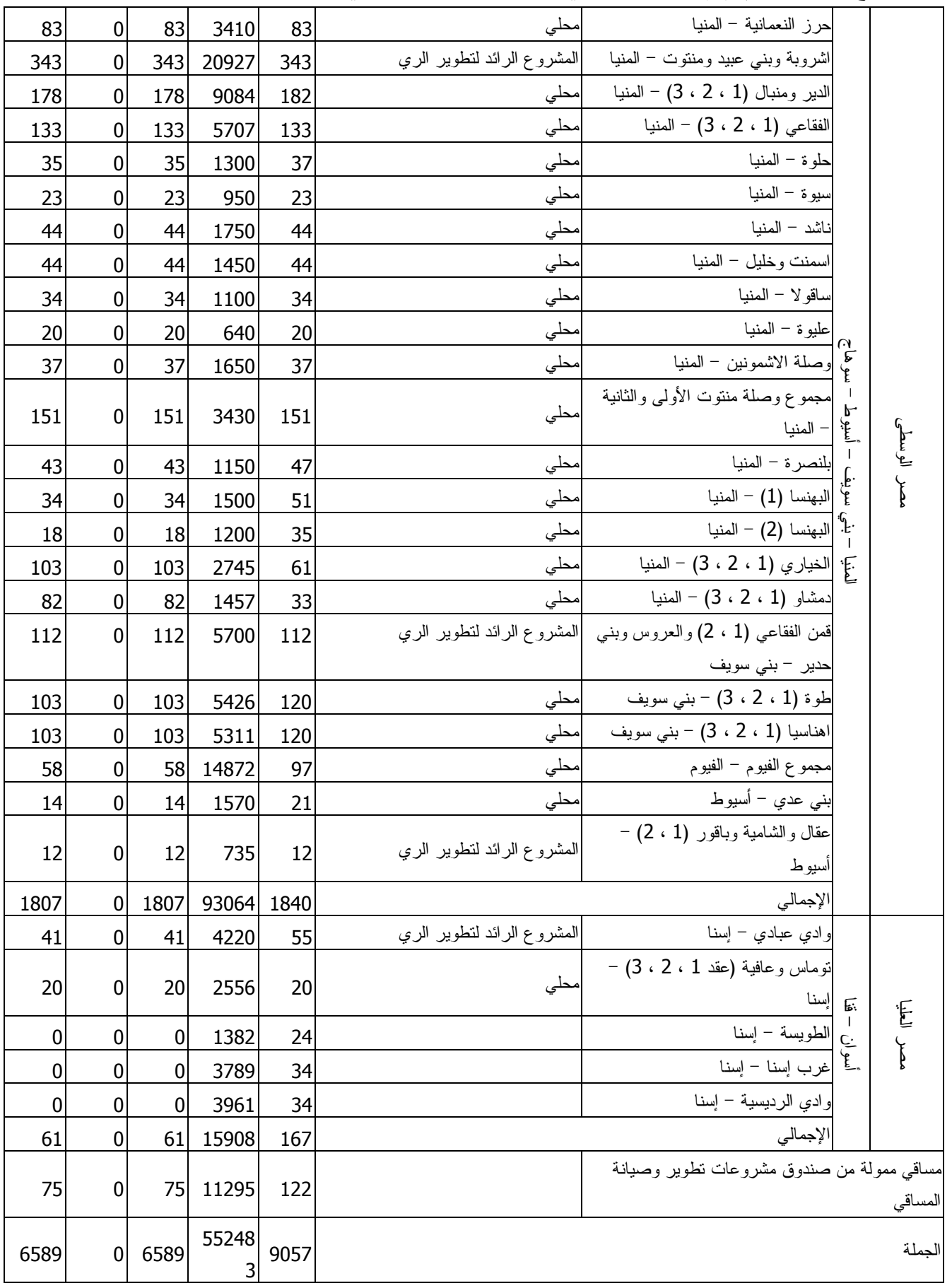




\section{الملخص والتوصيات}

يعتبر إنشاء رو ابط مستخدمي مباه الري من أليات تتفبذ مشروع تطـــوير الــري الحقلــى ،

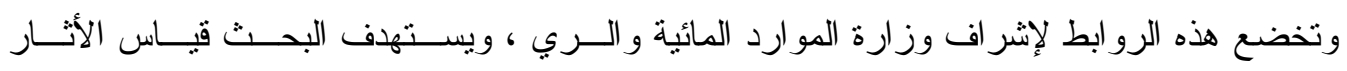

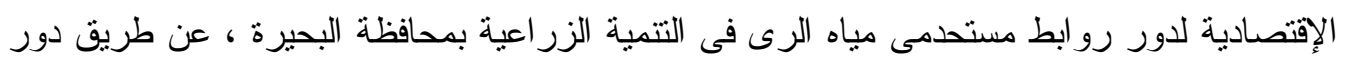

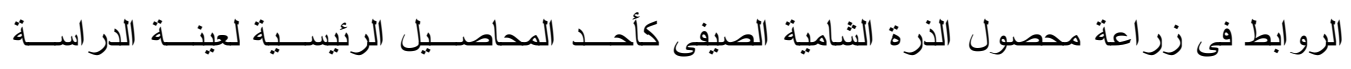

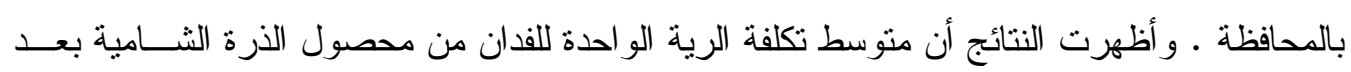

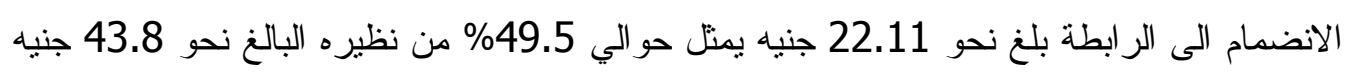

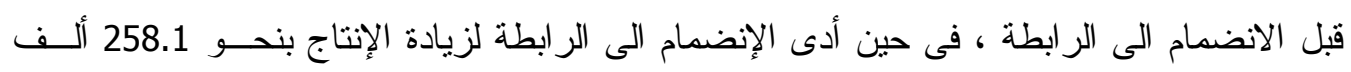

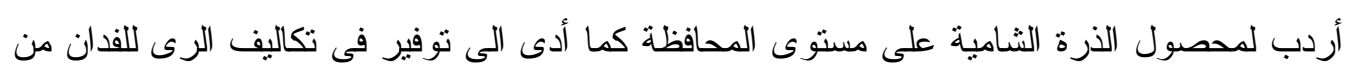

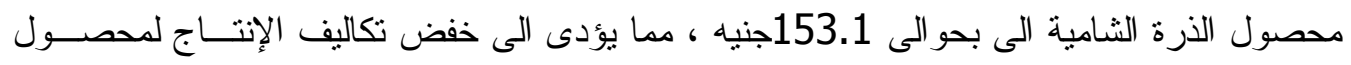

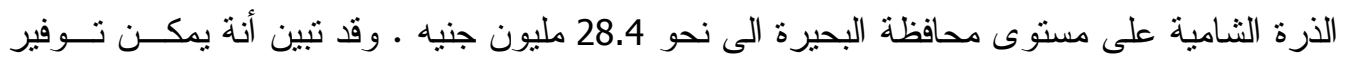

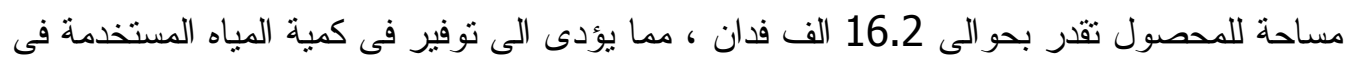

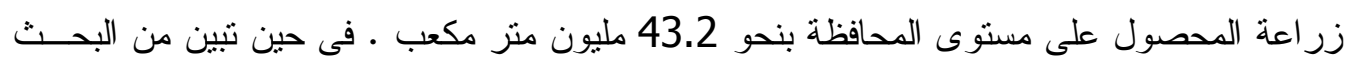

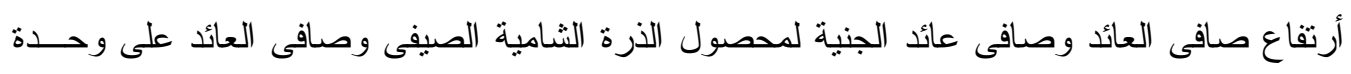

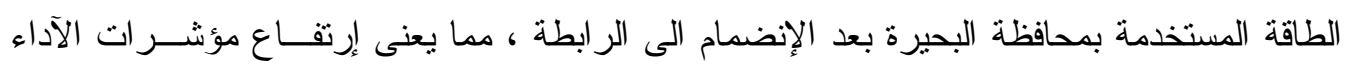

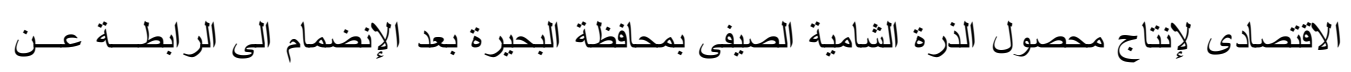

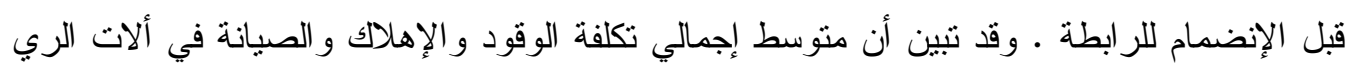

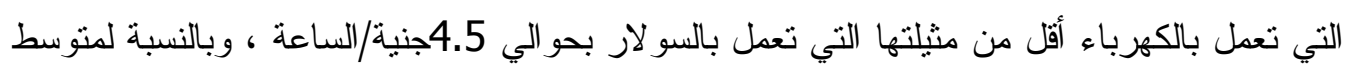

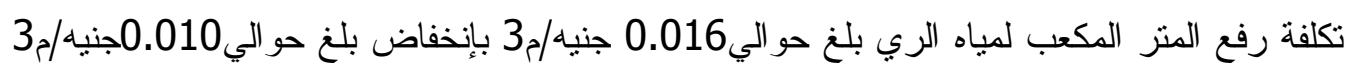

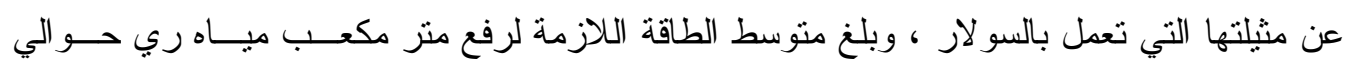

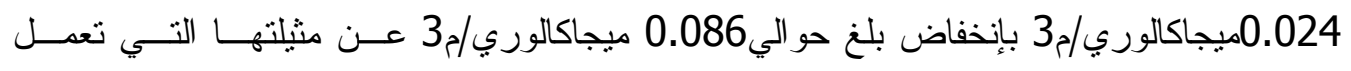

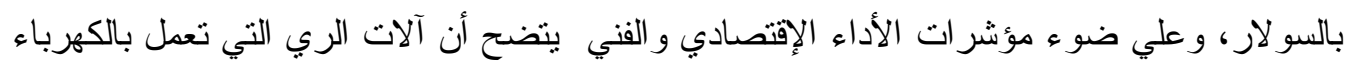

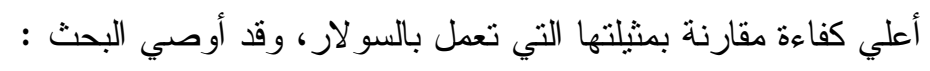

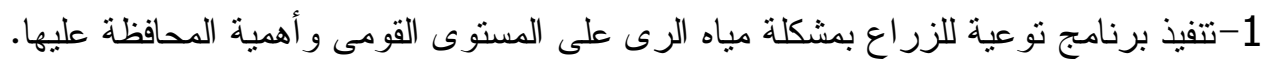

$$
\text { 2- العمل على تشجيع الإنضمام لروابط مستخدمى المياه . }
$$

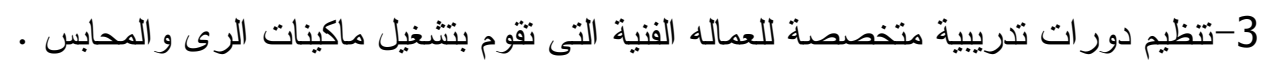

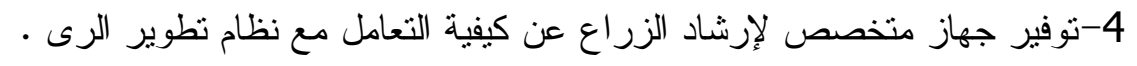
5- العمل على صدور قانون لتنظيم أعمال رو ابط مستخدمى المياه . 